IJBPAS, November, 2020, 9(11): 3024-3032

ISSN: 2277-4998

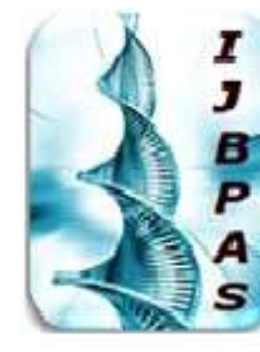

International Journal of Biology, Pharmacy

and Allied Seiences (IJBPAS)

'A Bridge Betusen raboratory and QRendo'

WwW.ibpas.com

PHARMACOKINETIC AND PHARMACODYNAMIC INTERACTION OF ALLICIN WITH GLIMEPIRIDE IN DIABETIC RATS

\title{
SUMALATHA $\mathbf{G}^{1^{*}}$ AND VIDYAVATHI $\mathbf{M}^{2}$
}

1: Max Institute of Pharmaceutical Sciences, Khammam, Telangana

2: Institute of Pharmaceutical Technology, Sri Padmavati Mahila Visvavidyalayam (Women's University), Tirupati, Andhra Pradesh, India

*Corresponding Author: G. Sumalatha: E Mail: suma.pharmacy@gmail.com

Received $14^{\text {th }}$ April 2020; Revised $4^{\text {th }}$ May 2020; Accepted 29 ${ }^{\text {th }}$ May 2020; Available online $1^{\text {st }}$ Nov. 2020

https://doi.org/10.31032/IJBPAS/2020/9.11.5260

\section{ABSTRACT}

The aim of the study was to determine the potential influence of Allicin on pharmacokinetics and pharmacodynamics of Glimepiride in alloxan induced diabetic rats. In this study, alloxan monohydrate $(120 \mathrm{mg} / \mathrm{kg})$ was used to induce diabetes in rats. These rats were divided into 5 groups $(\mathrm{n}=6))$. Group 1 was considered as control, group 2 treated with Glimepiride, group3 with Allicin, group 4 and 5were pretreated with Allicin for single day and for eight days respectively, by the end of the Allicin pretreatment Glimepiride was given. Blood samples were collected by retro orbital plexusat different time intervals and pharmacokinetic and pharmacodynamic parameters were measured. The total antioxidant status was also estimated by sub acute treatment of above groups. Allicin significantly increased the area under the curve (AUC) of glimepiride in both single and multiple dose study, $\mathrm{C}_{\max }, \mathrm{AUC}_{\mathrm{tot}}$ and MRT were also increased. In pharmacodynamic study, the glucose levels were significantly reduced upon pre treatment with Allicin.The total antioxidant status was gradually more increased in Allicin - Glimepiride treated group when compared with Allicin, Glimepiride alone treated (group 2 and 3) and control groups. The results in present study revealed that combination of Glimepiride with Allicin enhances the bioavailability and hypoglycemic effect of Glimepiride due to inhibition of CYP2C9 enzyme which suggested that Allicin might be beneficial as an adjuvant for the treatment of diabetes with Glimepiride in a proper dose.

Keywords: CYP2C9, Allicin, Glimepiride, Pharmacokinetic, Pharmacodynamic, enzyme inhibition 


\section{INTRODUCTION}

The use of herbal drugs along with prescription medicines became routine in present days. Majority of the modern medicines in India are derived from natural source [1, 2]. It is predicted that India will have the greatest increase in diabetes and will be the largest number of diabetic patients in the world. Inadequacies in current approach for treatment have led many patients to consider other natural alternative medicines. Complementary and alternative medicine (CAM) is defined by national centre for CAM as a group of diverse medical and health care system, practices and products that are not presently considered to be part of conventional medicine but there is no evidence of safety and efficacy. Worldwide around 400 herbs and plant preparations are reported to have beneficial effects in the treatment of diabetes mellitus [3-5].

Allicin (diallylthiosulphinate) is one of the active compounds of freshly crushed Garlic (Allium sativum). Garlic is considered to be a natural medicine against variety of human ailments including various bacterial, viral and fungal infections, antithrombotic, anticancer, antioxidant and antidiabetic activities [6, 7]. Allicin is proved to be effective in controlling diabetic complications and effective in reducing insulin resistance [8]. Glimepiride is a sulphonylurea oral hypoglycemic agent which is widely used for the treatment of type 2 diabetes. It is beneficial in certain diseases when given along with conventional drugs. It produces hypoglycemic effect by stimulating insulin secretion from $\beta$-cells of pancreas. The hypoglycemic effect of Glimepiride can be altered by co administration with some herbal drugs ex: curcuma longa, carica papaya.

Thus, there is a need to study the interaction between Glimepiride and other drugs to avoid adverse effects or to find benefits. Many drug interactions are as a result of induction or inhibition of CYP enzymes. There are several in vitro reports of Allicin on inhibition of CYP 450 especially CYP2C9 [9], which may lead to change in the bioavailability of coadministered drugs. Hence, there is a possibility of Allicin for the metabolic inhibition of Glimepiride as it is metabolized by CYP 2C9 liver microsomal enzymes [10].

In view of the above reports the present study was aimed at investigation of the effect of allicin on pharmacokinetics and pharmacodynamics of Glimepiride.

MATERIALS AND METHODS

Materials: 


\section{Drugs and chemicals:}

Glimepiride was obtained from Dr. Reddy's laboratories (Hyderabad, India). Methanol (HPLC-grade), potassium dihydrogen orthophosphate and orthophosphoric acid of AR grade were procured from Merck Specialties Pvt. Ltd., Mumbai. Ascorbic acid, $\alpha, \alpha$-diphenyl- $\beta$-picrylhydrazyl (DPPH), and alloxon were purchased from Hi Media Laboratories Pvt. Ltd, Mumbai. Water for analytical purpose is double distilled, filtered by using direct-Quvmillipore system. All other chemicals used were of analytical grade.

\section{Animals and diet:}

Male Albino Wistar rats weighing 180-250 g were purchased from Mahaveer enterprises, Hyderabad, India. The animals were housed in standard polypropylene cages and maintained under standard laboratory conditions (12:12 $\mathrm{h}$ light and dark cycle; at an ambient temperature of $25 \pm 5^{\circ} \mathrm{C} ; 35-60 \%$ of relative humidity). The animals were fed with standard rat pellet diet and water ad libitum. All experimental protocols were approved by the Institutional animal ethics committee (1533/PO/a/11/CPCSEA).

\section{METHODS}

Induction of diabetes in rats: Rats were deprived from food for 16 hours before the induction of diabetes. Diabetes was induced by a single intra peritoneal injection of aqueous alloxan monohydrate $(120 \mathrm{mg} / \mathrm{kg})$ solution [11]. After $72 \mathrm{~h}$, blood samples were collected from rats by retro orbital puncture and the serum was analyzed for glucose levels. Animals with blood glucose level $>250 \mathrm{mg} / \mathrm{dl}$ were considered as diabetic and were used for the study.

Grouping of diabetic rats and treatment: Diabetic rats were divided into 5 groups Group-1 rats were considered as diabetic control which were treated with normal saline. Group 2 rats were administered with Glimepiride (1 mg/Kg P.O.). Group 3 rats were treated with Allicin $(20 \mathrm{mg} / \mathrm{Kg})$. Group 4 rats were treated with Allicin $(20 \mathrm{mg} / \mathrm{kg})$ followed by Glimepiride for single dose interaction (SDI) study and Group 5 rats were pre-treated with Allicin for 7 days and on $8^{\text {th }}$ day Allicin $(20 \mathrm{mg} / \mathrm{kg})$ followed by Glimepiride (1 $\mathrm{mg} / \mathrm{Kg})$ for multiple dose interaction (MDI) study. Blood samples were collected after fasting for $16 \mathrm{~h}$ with water ad libitum from retro-orbital vein puncture [12] using heparinized capillary tubes at 0, 2, 4, 6, 8,12 and $24 \mathrm{~h}$. Serum was separated after centrifugation at $8000 \mathrm{rpm}$ for $15 \mathrm{~min}$ and used for further analysis.

\section{Estimation of Pharmacokinetic parameters:}

Different pharmacokinetic parameters of Glimepiride in groups 2, 4 and 5 were 
determined by HPLC analysis of serum samples collected at various time intervals.

\section{HPLC analysis}

Serum Glimepiride concentration (group 2, 4 and 5) was determined by reverse phase HPLC [13]. The solvent delivery system was a shimadzu pump model LC - 20 AD (Japan) and the column used was lichrosphere 100 RP $\mathrm{C}_{18}$ column, effluent was monitored with SPD-M10Avp diode array detector at 230 nm. The mobile phase consisting of methanol: $10 \mathrm{~mm}$ potassium dihydrogenortho phosphate $(\mathrm{pH} \mathrm{3.0)},(80: 20 \mathrm{v} / \mathrm{v})$, at a flow rate of $1.0 \mathrm{ml} / \mathrm{min}$. was used. All the collected serum samples were denatured by methanol and then centrifuged at $8000 \mathrm{rpm}$ for $15 \mathrm{~min}$. and supernatant was separated. Then, $20 \mu l$ of clear supernatant was injected into the HPLC system for quantification of Glimepiride in serum at different time intervals using calibration curve developed.

Estimation of serum glucose level in Pharmacodynamic study

The glucose concentration in different blood samples collected from the above mentioned groups of rats at various time intervals was determined using glucose oxidase-peroxidase method [14] for assessment of hypoglycemic activity of Glimiperide in diabetic rats.

Estimation of total antioxidant effect:
The total antioxidant effect in diabetic pretreated rats was estimated by DPPH method to find the influence of Allicin, Glimepiride combination therapy on antioxidant activity which support the antidiabetic effect.

Overnight fasted diabetic rats were divided into 4 groups, group 1, as a control, group 2 administered with Glimepiride, group 3 treated with Allicin and group 4 treated with Allicin followed by Glimepiride. They were treated once a day for 28 days and blood samples were collected at 7, 14, 21 and 28 days of treatment and used to determine antioxidant activity by DPPH method [15]. Ascorbic acid was used as a reference standard. The standard graph was prepared using ascorbic acid. The antioxidant activity was determined by the standard graph and values were expressed in terms of $\mathrm{nM}$ of ascorbic acid.

\section{Statistical analysis:}

The pharmacokinetic parameters were calculated using Kinetica Soft-ware (version 4.4.1). All values of pharmacokinetic and pharmacodynamic studies were expressed as mean \pm SD. The data were statistically evaluated using one way analysis of variance (ANOVA) followed by post hoc Dunnet's tmultiple comparison tests using Graph Pad Prism 5 computer software. Values 
corresponding to $\mathrm{p} \leq 0.05$ were considered as significant.

\section{RESULTS}

Pharmacokinetics of Glimepiride in diabetic rats:

The serum concentration of Glimepiride in different groups of animals at various time intervals was calculated based on the area of Glimepiride peak observed (at 5.862min, Figure 1) in HPLC chromatogram and with the help of its calibration curve developed priorily. Then, mean values of various pharmacokinetic parameters of Glimepiride in the presence of Allicin in diabetic rats were calculated and are shown in Table 1. The pharmacokinetic parameters of Glimepiride like $\mathrm{AUC}_{0-\mathrm{n}}, \mathrm{AUC}_{\text {tot }}, \mathrm{C}_{\max }, \mathrm{t}_{1 / 2}$, MRTand clearance were altered significantly with single and multiple dose interaction studies when compared with Glimepiride alone.

\section{Pharmacodynamics of Glimepiride}

The mean serum glucose level and percentage of glucose reduction was determined to find the effect of Allicin on the hypoglycemic action of Glimepiride in the pretreated diabetic rats and its results are shown in Table 2. The data revealed that there is a maximum reduction of serum glucose level (57.8\%) in Allicin and Glimepiride (MDI) $(51.8 \%$ in SDI)pretreated group when compared with Glimepiride (46.73\%) and Allicin (44.72\%) alone treated groups at $6^{\text {th }} \mathrm{hr}$ respectively.

\section{Antioxidant effect in diabetic rats:}

The antioxidant activity in different groups of animals is shown in Figure 2. The AllicinGlimepiride treated group has shown more increased in total antioxidant effect when compared with Allicin, Glimepiride alone treated and control groups.

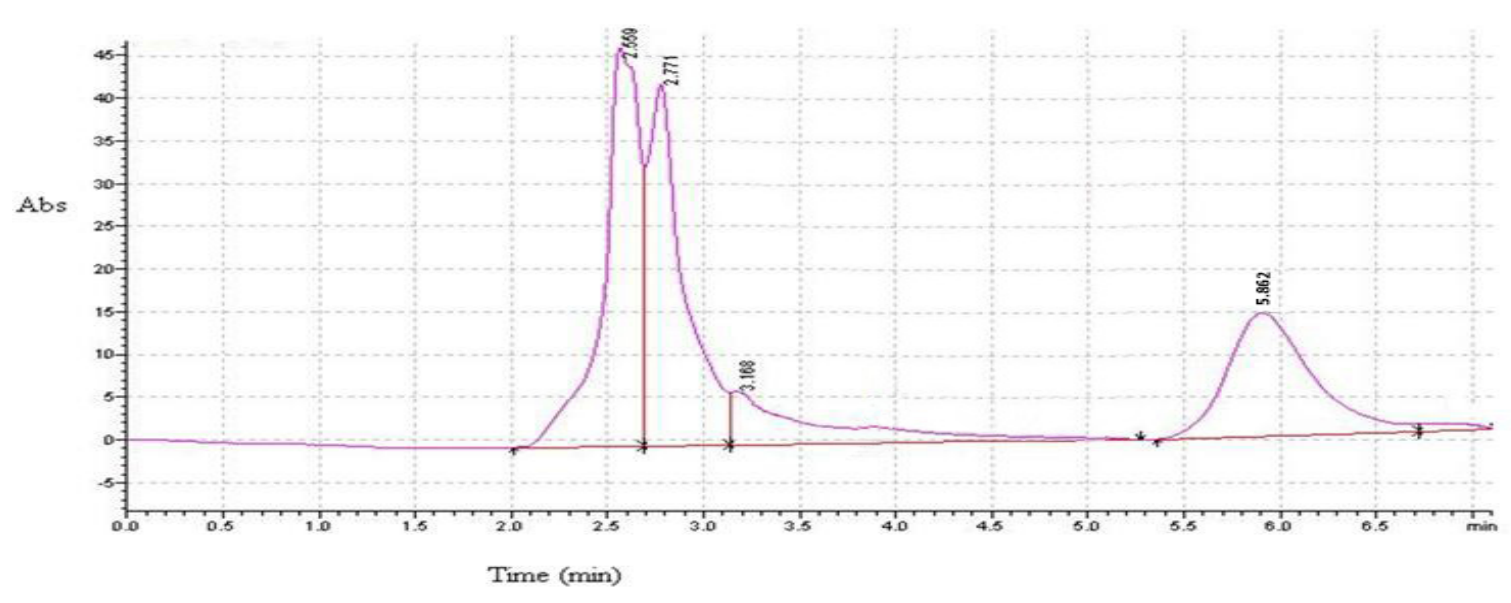

(C)

Figure 1: HPLC chromatogram of Glimepiride in rat serum sample 
Table 1: Pharmacokinetic Parameters of Glimepiride in different groups of diabetic rats

\begin{tabular}{|c|c|c|c|}
\hline PK parameters & $\begin{array}{l}\text { Group } 2 \text { (Treated } \\
\text { with Glimepiride) }\end{array}$ & $\begin{array}{c}\text { Group } 4 \text { (Treated } \\
\text { with Glim+Alli)(SDI) }\end{array}$ & $\begin{array}{c}\text { Group } 5 \text { (Treated with } \\
\text { Glim+Alli)(MDI) }\end{array}$ \\
\hline$C_{\max }(\mu \mathrm{g} / \mathrm{ml})$ & $18.23 \pm 0.82$ & $21.6+2.4 *$ & $28.26 \pm 1.46 * *$ \\
\hline$T_{\max }(h)$ & 2 & 2 & 2 \\
\hline $\operatorname{AUC}_{0-\mathrm{n}}(\mu \mathrm{g} / \mathrm{ml} \mathbf{h})$ & $68.02 \pm 2.54$ & $80.32+3.5$ ** & $113.64 \pm 3.24 * *$ \\
\hline $\mathrm{AUC}_{\text {tot }}(\mu \mathrm{g} / \mathrm{ml} \mathrm{h})$ & $70.62 \pm 2.01$ & $92.24+2.8 * *$ & $128.28 \pm 3.84^{* * *}$ \\
\hline$t_{1 / 2}(h)$ & $1.96 \pm 0.62$ & $2.06+3.2$ & $3.07 \pm 0.82 *$ \\
\hline MRT (h) & $3.5 \pm 0.4$ & $5.9+1.6 * *$ & $6.26 \pm 0.2 * *$ \\
\hline$C L_{t}(\mathrm{ml} / \mathrm{min})$ & $130.2 \pm 1.59$ & $102.4+2.3$ ** & $98.2 \pm 1.8^{* *}$ \\
\hline$V_{d}(m l)$ & $38.6 \pm 5.29$ & $38.9+2.4$ & $22.4 \pm 2.6^{* *}$ \\
\hline
\end{tabular}

All values are expressed as mean $\pm \mathrm{SD}(\mathrm{n}=6) ;{ }^{*} \mathrm{p}<0.05 ; * * \mathrm{p}<0.01$ considered as significant when compared with group 2

Table 2: Mean serum glucose levels and percentage reduction of serum glucose levels at different time intervals

\begin{tabular}{|c|c|c|c|c|c|c|c|c|}
\hline \multirow{2}{*}{$\begin{array}{c}\text { Group } \\
\text { no. }\end{array}$} & \multirow{2}{*}{ Treatment } & \multicolumn{7}{|c|}{ Serum glucose levels $(\mathrm{mg} / \mathrm{dl})$ and \% reduction of serum glucose levels } \\
\hline & & $0 \mathrm{hr}$ & $2 \mathrm{hr}$ & $4 \mathrm{hr}$ & $6 \mathrm{hr}$ & $8 \mathrm{hr}$ & $12 \mathrm{hr}$ & $24 \mathrm{hr}$ \\
\hline 1 & Control & $334.56 \pm 2.4$ & $\begin{array}{c}332.58 \pm 1.54 \\
(0.49 \%)\end{array}$ & $\begin{array}{c}332.42 \pm 1.8 \\
(0.65 \%)\end{array}$ & $\begin{array}{c}331.68 \pm 1.46 \\
(0.85 \%)\end{array}$ & $\begin{array}{c}332.2 \pm 1.2 \\
(0.53 \%)\end{array}$ & $\begin{array}{c}332.8 \pm 2.0 \\
(0.54 \%)\end{array}$ & $\begin{array}{c}332.2 \pm 1.45 \\
(0.39 \%)\end{array}$ \\
\hline 2 & Glimepiride & $260.6 \pm 4.6$ & $\begin{array}{l}224.5 \pm 5.9 \\
(13.81 \%)^{*}\end{array}$ & $\begin{array}{c}189.46 \pm 9.4 \\
(27.34 \%) *\end{array}$ & $\begin{array}{l}138.05 \pm 6.8 \\
(46.73 \%)^{* *}\end{array}$ & $\begin{array}{l}156.15 \pm 8.6 \\
(40.88 \%)^{* * *}\end{array}$ & $\begin{array}{l}178.3 \pm 6.8 \\
(31.1 \%)^{* *}\end{array}$ & $\begin{array}{c}226.27 \pm 2.4 \\
(13.76 \%)^{*}\end{array}$ \\
\hline 3 & Allicin & $276.5 \pm 4.6$ & $\begin{array}{c}247.3+9.48 \\
(10.2 \%)^{*}\end{array}$ & $\begin{array}{c}223.46 \pm 9.4 \\
(19.3 \%) *\end{array}$ & $\begin{array}{l}153.05+6.8 \\
(44.72 \%)^{* * *}\end{array}$ & $\begin{array}{l}162.5 \pm 8.6 \\
(41.5 \%)^{* *}\end{array}$ & $\begin{array}{c}220.3++6.8 \\
(20.1 \%)^{*}\end{array}$ & $\begin{array}{c}242.27++2.4 \\
(13.4 .7 \%)^{*}\end{array}$ \\
\hline 4 & $\begin{array}{c}\text { Allicin+ } \\
\text { Glimepiride } \\
\text { (SDI) }\end{array}$ & $272.2 \pm 6.3$ & $\begin{array}{c}234.14 \pm 8.5 \\
(15.4 \%)^{*}\end{array}$ & $\begin{array}{c}215.6 \pm 9.4 \\
(20.8 \%)^{*}\end{array}$ & $\begin{array}{l}136.9 \pm 7.7 \\
(51.8 \%)^{* *}\end{array}$ & $\begin{array}{l}142.8 \pm 8.9 \\
(45.9 \%)^{* *}\end{array}$ & $\begin{array}{l}156.4 \pm 9.2 \\
(42.6 \%)^{* *}\end{array}$ & $\begin{array}{l}196.6 \pm 6.4 \\
(26.4 \%)^{*}\end{array}$ \\
\hline 5 & $\begin{array}{c}\text { Allicin + } \\
\text { Glimepiride } \\
\text { (MDD) }\end{array}$ & $253.2 \pm 6.3$ & $\begin{array}{c}201.14 \pm 8.5 \\
(20.2 \%)^{*}\end{array}$ & $\begin{array}{l}192.6 \pm 9.4 \\
(24.8 \%)^{*}\end{array}$ & $\begin{array}{c}112.9 \pm 7.8 \\
(57.81 \%)^{* * *}\end{array}$ & $\begin{array}{l}104.8+8.8 \\
(59.9 \%)^{* * *}\end{array}$ & $\begin{array}{l}120.4 \pm 8.2 \\
(52.6 \%)^{* * *}\end{array}$ & $\begin{array}{l}176.6 \pm 6.4 \\
(34.4 \%)^{* * *}\end{array}$ \\
\hline
\end{tabular}

All values are expressed as mean $\pm \mathrm{SD}(\mathrm{n}=6), * \mathrm{P}<0.05, * * \mathrm{P}<0.01$ considered as significant when compared with control (group 1)

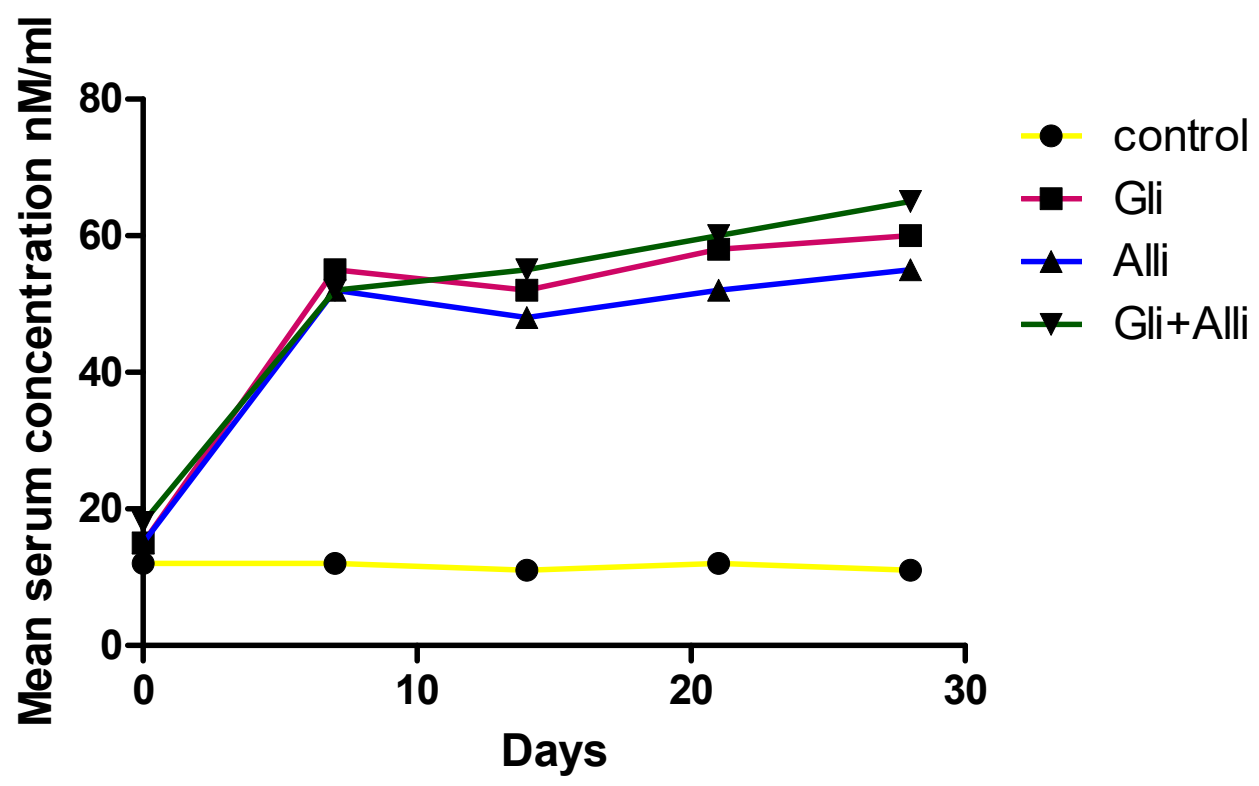

Figure 2: Antioxidant effect of Allicin and Glimepiride in diabetic rats (All values are expressed in mean $\underline{\mathbf{S D}}(\mathrm{n}=6)$ ) 


\section{DISCUSSION}

Diabetes is a chronic metabolic disorder which needs prolonged treatment for maintenance of normal blood glucose levels and to control several complications induced by disease. The objective of the present study was to determine the influence of Allicinon the pharmacokinetics and pharmacodynamic behavior of Glimepiride in diabetic rats. Hence, the influence of Allicin was found by both SDI and MDI studies in Alloxan induced diabetic rats.

The PK parameters of Glimepiride $\left(\mathrm{C}_{\max }\right.$, $\mathrm{AUC}_{0-\mathrm{n}}, \mathrm{AUC}_{\text {tot, }}$, and MRT) were increased significantly in presence of Allicin. It revealed that, either the absorption of Glimepiride is enhanced or the metabolism of Glimepride is inhibited. And there was no change in $\mathrm{T}_{\max }$ indicated that, there is no influence of Allicin on absorption of Glimepiride. Thus the present study confirmed that the metabolism of Glimepiride was decreased by Allicin through enzyme inhibition effect of Allicin on CYP2C9 which is responsible for metabolism of Glimepiride.

In pharmacodynamic study, the increase in hypoglycemic action by concomitant administration of Glimepiride with allicin (MDI) was more when compared with other groups. The maximum reduction of serum glucose levels in groups treated with combination were 51.8\% (SDI) and 57.89\% (MDI) at $6^{\text {th }}$ hr**P $<0.01$ when compared with Glimepiride (46.73\%), Allicin (44.72\%) alone treated groups at $6^{\text {th }}$ hour, which suggested the enhancement of glucose reduction capacity of Glimepiride in presence of Allicin in diabetic rats. These results are coinciding with the results of PK parameters i.e. increased $\mathrm{C}_{\max }$, $\mathrm{AUC}$ and MRT.

Serum total antioxidant effect also suggested that Allicin alone treated animals shown significant increase in free radical scavenging capacity when compared with control group. However the antioxidant effect of rats treated with Allicin-Glimepiride shown maximum effect when compared with Allicin or Glimepiride alone treated groups. This indicated that combination of Allicin and Glimepiride produce more antioxidant effect than individual drugs.

\section{CONCLUSION}

The results of increased $\mathrm{C}_{\max }$, AUC of Glimepiride in presence of Allicin suggested an interaction is possible in Glimepiride, Allicin combination therapy due to decreased metabolism of Glimepiride by CYP2C9 inhibition with Allicin. Combination of Glimepiride with Allicin also enhanced the hypoglycemic effect of Glimepiride. Hence, the combination has a beneficial effect in 
diabetic rats. So,a special attention in the alterations of doses of Glimepiride may be required if used along with Allicin containing preparations to avoid the complications.

\section{ACKNOWLEDGEMENT}

The author acknowledges the principal and management of Vaagdevi College of pharmacy, for providing necessary facilities during animal studies.

\section{REFERENCES}

[1] Sandhya W, Global health care challenge: Indian experiences and new prescriptions. E J Biotech, 2004, 7: 217-223.

[2] K.Eswar kumara, PD. Jyotsna rani, K. Raghuram, P.swathi and MN gupta, pharmacokinetic and pharmacodynamic drug interaction of Gliclazide and Risperidone in animal models. Int. J Pharm and Pharm Sci, 2012, 4(2), 659-662.

[3] Eisenberg DM, Davis RB, Ettner SL, Appel S, Wilkey S, Trends in alternative medicine use in the United States, 1990-1997: results of a follow-up national survey. $\mathrm{J}$ of the Amer Med Assoc, 1998, 280 (18): 1569-1575.

[4] Egede LE, Ye X, Zheng D, Silverstein MD .The prevalence and pattern of complementary and alternative medicine use in individuals with diabetes. Diabetes Care, 2002, 25: 324-329.

[5] Sing S, VeenaG and Deepak Y. Antihyperglycemic and antioxidative ability of stevia rebaudiana (bertoni) leaves in diabetes induced mice. IntJ of Pharm and Pharmaceu Sci. 2013, 5(2), 297-302.

[6] Hermann $\mathrm{R}$ and Von Richter $\mathrm{O}$. Clinical evidence of herbal drugs as perpetrators of pharmacokinetic drug interactions, Planta Medica, 2012, 78(13), 1458-1477.

[7] Rahman K. Historical perspective on garlic and cardiovascular disease, The J Nutr., 2001, 131(3), 977S-979S.

[8] Raju P and Sanjay KB. Garlic as an Anti-diabetic Agent: Recent Progress and Patent Reviews Recent Pat Food Nutr \& Agri, 2013, 5(1)

[9] Beatrice EH, Danny DS, Jeannie SM, Tot B, Linda R, Ziping Y, Rodney JY, Effect of Garlic on cytochromes P450 2C9 and 3A4-mediated drug metabolism in human hepatocytes, Scientia. Pharmaceutica,2010, 78(3): 473-481 .

[10] RobkampR, wernicke-Panten K, Draeger E. Clinical profile of the novel sulphonylurea glimepiride. 
Diabetes Res ClinPr.1996; 31, s33-

42.

[11] Chattopadhyaya A, Ramanathan

Das M, Bhattacharya J, Animal models in experimental diabetes mellitus.Ind J ExpBiol 1997; 35:1141-1145.

[12] Wannaporn S, Aramsri M, Sirintorn YA, Sirichai A, Preventive effect of grape seed extract against highfructose diet-induced insulin resistance and oxidative stress in rats. Food and ChemTox. 2010; 48: 1853-1857.

[13] Sujatha S, Sandhya Rani T, Veeresham C. Determination of Glimepiride in rat serum by RPHPLC method. Ameri J Analy Chem., 2011, 2: 152-157.

[14] Trinder P. Determination of blood glucose using 4-amino phenazone as oxygen acceptor. J Clin Pathol., 1969; 22: 246-b.

[15] Reddy YN, Murthy SV, Krishna DR, Prabhakar MC. Role of free radicals and antioxidants in tuberculosis patients. Indian $\mathrm{J}$ Tuberc., 2004; 51: 213-218. 